\title{
Four Social Theories for Global Health
}

\section{Citation}

Kleinman, Arthur. 2010. Four Social Theories for Global Health. The Lancet 375 (9725): 1518-1519.

\section{Published Version}

doi:10.1016/S0140-6736(10)60646-0

\section{Permanent link}

http://nrs.harvard.edu/urn-3:HUL.InstRepos:5142663

\section{Terms of Use}

This article was downloaded from Harvard University's DASH repository, and is made available under the terms and conditions applicable to Open Access Policy Articles, as set forth at http:// nrs.harvard.edu/urn-3:HUL.InstRepos:dash.current.terms-of-use\#OAP

\section{Share Your Story}

The Harvard community has made this article openly available.

Please share how this access benefits you. Submit a story.

\section{Accessibility}




\section{The art of medicine \\ Four social theories for global health}

Global health, many would agree, is more a bunch of problems than a discipline. As such it lacks theories that can generalise findings-through an iterative process of knowledge construction, empirical testing, critique, new generalisation, and so oninto durable intellectual frameworks that can be applied not only to distinctive health problems, but to different contexts and future scenarios. This lack may or may not have slowed progress in developing and implementing programmes, but it surely has limited the education of practitioners and the emergence of an intellectually robust field. There is no contradiction between global health being both evidence-based and theory-oriented. After all, this is what characterises the social sciences and natural sciences, which together create the academic platform for global health, even if the profession of medicine, another core component, has not been a theory-rich field.

During the past 2 years, I had the privilege of teaching a course on global health to Harvard undergraduates with my colleagues Jim Kim, Paul Farmer, Anne Becker, and Salmaan Keshavjee. We started off with several social theories that we used to make more general sense of individual case studies in global health implementation, but we ultimately honed our exploration down to four key social theories.

The first social theory of global health is the unintended consequences of purposive (or social) action. Introduced by the sociologist Robert Merton, this theory holds that all social interventions have unintended consequences, some of which can be foreseen and prevented, whereas others cannot be predicted. Therefore, all social action needs to be routinely evaluated for unintended consequences that might lead to the modification of programmes, and even, if the consequences are serious enough, their termination. This theory would seem to be the social science equivalent of medicine's "first, do no harm", but it goes beyond that ancient saw to reason that every action can have unintended effects and also that certain of those may not necessarily be harmful. Global health is filled with illustrations of unintended and often harmful consequences of programmes, such as those following coercive vaccination during the smallpox eradication campaigns in India, which led to individual and community resistance to later vaccination campaigns. An unintended consequence of China's one child per family population control policy is the sexual revolution it created.

Second, is the social construction of reality, as introduced by Berger and Luckmann in the 1960s, that has become foundational in the social sciences. It holds that the real world, no matter its material basis, is also made over into socially and culturally legitimated ideas, practices, and things. Hence the spread of the H1N1 influenza virus is made over globally into the socially threatening and culturally fearful swine flu epidemic; cancer takes on the meaning as the dread disease in the USA in the early 20th century; mental illness is stigmatised by the social construction of non-persons 
in China; a formerly authoritarian physician-patient relationship becomes increasingly egalitarian as cultural expectations change; and medications take on a social life of their own via informal networks and social marketing. Abortion becomes highly contentious in the USA but not in Japan, just as brain death becomes highly contentious in Japan but not in the USA. Global health problems and programmes can (and at times do) take on culturally distinctive significance in different local settings. This leads to a tension between global policies and local reality that is foundational to medical and public health practice. A corollary of the social construction of reality is that each local world-a neighbourhood, a village, a hospital, a network of practitioners/researchers-realises values that amount to a local moral context that influences the behaviour of its members. For global health, the implication is that those local moral worlds can affect everything from smoking cessation interventions to HIVIAIDS prevention and treatment programmes.

The third social theory is that of social suffering, which provides a framework that holds four potentially useful implications for global health. First, that socioeconomic and sociopolitical forces can at times cause disease, as is the case with the structural violence of deep poverty creating the conditions for tuberculosis to flourish and for antibiotic resistance to develop. Second, that social institutions, such as health-care bureaucracies, that are developed to respond to suffering can make suffering worse. Examples of this are hospital-based medical errors or the failure of the US Veterans Administration clinics to adequately diagnose and treat the psychiatric trauma among soldiers returning from the current wars in Iraq and Afghanistan. Third, social suffering conveys the idea that the pain and suffering of a disorder is not limited to the individual sufferer, but extends at times to the family and social network, as is the case when Alzheimer's disease has created such serious cognitive impairment in the patient that he or she expresses no discomfort when the adult children experience deep loss and frustration. For global health programmes, the implication is that the family and network may also be in need of health interventions and are often influential in help seeking and adherence. Finally, the theory of social suffering collapses the historical distinction between what is a health and what is a social problem, by framing conditions that are both and that require both health and social policies, such as in urban slums and shantytowns where poverty, broken families, high risk for violence are also the settings where depression, suicide, PTSD, and drug misuse cluster. While there are clearly occasions when health policy and social policy have different targets, in the poorest of communities the medical, the economic, and the political may often be inseparable.

Fourth, we draw on the concept of biopower, a term coined by Michel Foucault to model the way political governance increasingly exerted its effects via the control of bodies and populations. Social statistics in Europe grew out of the state's efforts to enumerate populations for purposes of social control, albeit that effort also had health-relevant consequences. Other examples include the way that during the era of 
radical collectivisation under Maoist policies in China in the 1960s and 1970s, the population control policy led to local cadres requiring village women in their reproductive years to post the dates of their menstrual cycles on the doors of their homes as a means of surveillance and birth control. Working with this theory, Adriana Petryna introduced the term biological citizenship to make sense of the postChernobyl disaster situation in the Ukraine. Although radiation scientists certified only a few hundred victims of radiation exposure, a much greater number of people claimed disability from the accident, and in the process, a new identity: citizens biologically defined by this trauma as deserving of compensation from a caring state that exerts the power of governance via the welfare rolls.

In his powerful ethnography of failed development projects in the 1970s and 1980s in Lesotho-one of the world's poorest countries-James Ferguson showed that the government used biopower to deal with international agencies like the World Bank by getting road building, funded ostensibly to improve transportation to clinics, whereas the government's deep motive was being able to move the Army from one part of the country to another for political purposes. The UN-system and its agencies as well as individual nation-states frequently govern via biopower so that global health programmes can come to serve ulterior purposes. In post-conflict states like Liberia and Sierra Leone, governance is dominated by the UN system agencies and nongovernmental organisations (NGOs) that exert political and social control via programmes focused on the management and rehabilitation of trauma. Biopower becomes an increasingly important issue as global health programmes are scaled-up by nation-states.

These four theories, and their derivatives, do not exhaust the social theories that are potentially salient for global health. Among other influential theories are, for example, those of the great German sociologist Max Weber on bureaucratic rationality and the predicament of institutionalising charismatic leadership. Weber's ideas are directly pertinent to understand how bureaucracies are indifferent as they become implementation bottlenecks for global health programmes and international and local NGOs falter after their founders depart, respectively. And, of course, all of these theories have their limitations and potential misuses which need to be taught along with their appropriate uses.

My colleagues and I have discovered that students appreciate being able to relate these theories to in-depth case studies in order to generalise knowledge and to develop a more systematic critical reflection on global health problems and programmes as a complement to epidemiological, health services, policy, and ethical studies. Social theories have a place in medicine as well as in global health. And one of the pedagogic responsibilities of medical humanities and social science programmes must be to introduce students to intellectual frameworks that lead to both a deeper critical reflection on disease and caregiving and new tools to improve 
practice. Clinically relevant theories, such as illness behaviour, explanatory models, and medicalisation are proven examples, but the potential range of social theories appropriate for medical practice is still much larger. Sadly, social scientists have at times used theories simply to attack medicine, not to improve medical practice. That is a failure of social science every bit as damaging as the profession of medicine's failure to seriously engage with social theories. The time has long since come to supercede this untenable situation and to make social theory another instrument of improving health and reforming health care.

Arthur Kleinman

Harvard University, Department of Anthropology, William James Hall Room 330

33 Kirkland Street, Cambridge, MA 02138, USA

kleinman@wjh.harvard.edu

\section{Further reading}

Merton RK. The unanticipated consequences of purposive social action. Am

Sociological Rev 1936; 1: 894-904.

Berger P, Luckmann T. The social construction of reality. Garden City: Anchor Books, 1967.

Kleinman A. What really matters. New York and Oxford: Oxford University Press, 2006.

Kleinman A, Das V, Lock M, eds. Social suffering. Berkeley: University of California Press, 1997.

Foucault M. The history of sexuality. London: Penguin, 1990.

Petryna A. Life exposed. Princeton: Princeton University Press, 2002.

Ferguson J. The anti-politics machine: "development", depoliticization, and bureaucratic power in Lesotho. Minneapolis: University of Minnesota Press, 1994.

Abramowitz S, Kleinman A. Humanitarian intervention and cultural translation: a review of the IASC Guidelines on Mental Health and Psychosocial Support in Emergency Settings. Intervention 2008; 6(3): 219-27.

Farmer P. Pathologies of power. Berkeley: University of California Press, 2005. 